\title{
Role of Employee in Introducing Modern Technological Tools for Improving the Productivity
}

\author{
K. Thiyagarajan, M. Shanmugapriya, C. Archanapriya
}

\begin{abstract}
Employee motivation is simply about succeeding in doing something. This provides an indication of job satisfaction and an employee's happiness in the company. My research is to analyze the various motivational factors in employees with respect to the need hierarchy of Maslow, to know the level of motivation in the company's employees, and to provide concrete suggestions for improving the quality of the organization.
\end{abstract}

Keywords - Motivation, commitment, job satisfaction, performance, comfortableness.

\section{INTRODUCTION}

Motivation is one of human behavior and performance's most important factors. This is one of the reasons managers instruction contributes to productivity at both organizational and individual levels[1]-[5]. Motivation is an integral part of the process of managing. An organization may have the best materials, machinery and other means of production, but all these tools are worthless as long as they are not used by people who are properly motivated.

\section{REVIEW OF LITERATURE}

Vuori and Okkonen (2012) claimed that motivation leads to information sharing through an intra-organizational social media platform that can help the company achieve its goals and objectives.

Aguinis et al. (2013) stated that monetary rewards can be a very powerful determinant of employee motivation and achievement that, in turn, can lead to significant performance returns at the company level.

\section{RESEARCH METHODOLOGY}

\section{A. Methods of Collection:}

Revised Manuscript Received on December 11, 2019

K. Thiyagarajan, Department of Science and Humanities, Bharath Institute of Higher Education and Research, Chennai, India. Email: thiyagu768@gmail.com

M. Shanmugapriya, Department of Science and Humanities, Bharath Institute of Higher Education and Research, Chennai , India. Email: priyashammu@gmail.com

C. Archanapriya, Department of Science and Humanities, Bharath Institute of Higher Education and Research, Chennai, India.. Email: Archanapriya854@gmail.com attach great importance to organizational motivation. Good

Primary sources - The primary data are in the form of "raw material" to which statistical methods are used for analyzing and interpreting purposes. The primary sources are consultation with workers, data collected by questionnaire[6]-[10].

Secondary sources - Secondary statistics are in the form of finished products as they have been handled in some way or other statistically.

\section{B. Question form Asked:}

The questionnaire consists of questions that are open ended, dichotomous, score, and ranking[23]-[25].

\section{Research variables:}

The study's main factor is the motivation of the worker. Indirect variables are rewards, interpersonal relationships, prospects for career development and framework for assessing results.

\section{Data analysis:}

Evaluation and interpretation is an important part of any type of analysis of inter-data[11]-[14]. The researcher will begin to identify the relationship between various data to help better understand the participants and make better decisions.

\section{RESULTS AND DISCUSSION}

\section{ANALYSIS OF VARIANCE ONE WAY-ANOVA}

Null hypothesis $\left(\mathbf{H}_{\mathbf{0}}\right)$ : There is no significance difference between experience level and age of the respondents.

Alternative hypothesis $\left(\mathbf{H}_{1}\right)$ : There is significant difference between the experience level and age of the respondents.

\begin{tabular}{|l|l|l|l|l|l|}
\hline ANOVA \\
\hline \multicolumn{2}{|l|}{ Experience } \\
\hline & $\begin{array}{l}\text { Sum of } \\
\text { Squares }\end{array}$ & Df & $\begin{array}{l}\text { Mean } \\
\text { Square }\end{array}$ & F & Sig. \\
\hline $\begin{array}{l}\text { Between } \\
\text { Groups }\end{array}$ & 2.237 & 3 & .746 & 1.101 & .358 \\
\hline $\begin{array}{l}\text { Within } \\
\text { Groups }\end{array}$ & 31.143 & 46 & .677 & & \\
\hline Total & 33.380 & 49 & & & \\
\hline
\end{tabular}




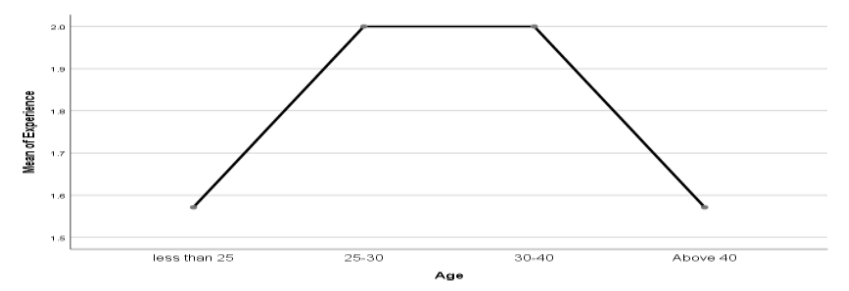

The significant value must be less than 0.05 (for $95 \%$ significant level).In this significance level is greater than 0.05.Therefore $\mathrm{H}_{0}$ is accepted. Therefore, there is no significance difference between experience level and age of the respondents[15]-[19].

\section{SUGGESTIONS}

- Promotion policies can be provided properly which makes employees motivated towards existing job and employee's performance towards the job also gets increased[20]-[22].

- Organisation should provide suitable and sufficient welfare facilities for the well- being of their employees while at work.

\section{CONCLUSION}

Motivation may be defined as the work the manager performs in order to induce subordinates to act in the desired manner by satisfying their needs and desired thus, motivation is concerned with how behaviour gets stated, is energised, sustained and directed. Motivation is symbiosis to both employees and employer.

\section{REFERENCES}

1) Vasanthi, S. \& Rabiyathul Basariya, S. 2019, "Influence of value analysis and cross training in industry", International Journal of Engineering and Advanced Technology, vol. 8, no. 6, pp. 1810-1811.

2) Velvizhi, R., Sri Gowtham, S. \& Jeya Priya, D. 2019, "Examination of early feedbacks for effective product retailing on E-commerce websites", International Journal of Engineering and Advanced Technology, vol. 8, no. 6 Special Issue 2, pp. 703-706.

3) Anuradha, C., Pothumani, S. \& Kavitha, R. 2019, "A novel method towards E-commerce", International Journal of Engineering and Advanced Technology, vol. 8, no. 6 Special Issue 2, pp. 535-538.

4) Thomas, J. \& Rabiyathul Basariya, S. 2019, "A study on the issues of financial ratio analysis", Indian Journal of Public Health Research and Development, vol. 10, no. 3, pp. 1079-1081.

5) Ramachandran, S. \& Rabiyathul Basariya, S. 2019, "Online marketing study on customer satisfaction and relationship", Indian Journal of Public Health Research and Development, vol. 10, no. 3, pp. 1072-1078.

6) Priya, R., Vinothini, G. \& Cor Jesu, C.D. 2019, "The mentor-protégé relationship for professional growth", Journal of Advanced Research in Dynamical and Control Systems, vol. 11, no. 9 Special Issue, pp. 1110-1119.

7) Jannifer Rani, N., Bina Pani, S. \& Nimisha, N.S. 2019, "A study on money back polices available in LIC", Journal of Advanced Research in Dynamical and Control Systems, vol. 11, no. 9 Special Issue, pp. 833-839.

8) Saillaja, V., Jhansi Rani, K. \& Catherine, R. 2019, "Global marketing management planning and organization", Journal of Advanced Research in Dynamical and Control Systems, vol. 11, no. 9 Special Issue, pp. 489-493.

9) Saillaja, V., Jhansi Rani, K. \& Catherine, R. 2019, "The new phase of marketing information system", Journal of Advanced Research in Dynamical and Control Systems, vol. 11, no. 9 Special Issue, pp. 482-488.

10) Thoufiqulla \& Raju, D.V. 2019, "Perception of indian investor towards investment in mutual funds with special reference to mip funds", Journal of Advanced Research in Dynamical and Control Systems, vol. 11, no. 5, pp. 177-183.

11) Jasmine, K.R.M. \& Basariya, S.R. 2018, "A study on the customers benefits on mutual funds", International Journal of Civil Engineering and Technology, vol. 9, no. 4, pp. 45-48.

12) Vasanthi, S. \& Basariya, S.R. 2019, "Pros and cons of on the job training versus off the job training", International Journal of Scientific and Technology Research, vol. 8, no. 10, pp. 671-674.

13) Pavithra, J. \& Ganesan, M. 2016, "A study on awareness and impact of micro-financial schemes", International Journal of Applied Business and Economic Research, vol. 14, no. 8, pp. 5449-5460.

14) Pavithra, J., Dilli Babu, P. \& Ambuli, T.V. 2014, "A study on budgetary control at Maruti Service Masters, Chennai", International Journal of Applied Business and Economic Research, vol. 12, no. 2, pp. 151-161.

15) Gunaraja, T.M. \& Venkatrama Raju, D. 2018, "Determining factors of organisational climate with reference to leadership styles", International Journal of Mechanical Engineering and Technology, vol. 9, no. 9, pp. 1327-1332.

16) Gunaraja, T.M. \& Venkatrama Raju, D. 2018, "The role of job satisfaction and training of employees in determining organisational climate of a selected industry", International Journal of Civil Engineering and Technology, vol. 9, no. 8, pp. 1266-1269.

17) Aarathy, T.S. \& Raju, D.V. 2018, "Performance appraisal and its effects on employees with respect to it sector in Chennai city", International Journal of Civil Engineering and Technology, vol. 9, no. 6, pp. 1535-1538.

18) Aarathy, T.S. \& Raju, D.V. 2018, "Employee perception towards performance appraisal system in IT sector", International Journal of Mechanical Engineering and Technology, vol. 9, no. 5, pp. 131-135.

19) Porselvi, W., Jublee, D. \& Sivanesan, G. 2018, "A study on factors influencing adoption of technology and innovation in banking industry, tamilnadu, India", International Journal of Mechanical Engineering and Technology, vol. 9, no. 5, pp. 789-800.

20) Akessa, G.M. and Dhufera, A.G., 2015. Factors That Influences Students Academic Performance: A Case of Rift Valley University, Jimma, Ethiopia. Journal of Education and Practice, 6(22), pp.55-63.

21) Miller, G. and Shih, C.C., 1999. A faculty assessment of the academic rigor of on-and off-campus courses in agriculture. Journal of Agricultural Education, 40, pp.57-65.

22) Tsinidou, M., Gerogiannis, V. and Fitsilis, P., 2010. Evaluation of the factors that determine quality in higher education: an empirical study. Quality Assurance in education, 18(3), pp.227-244.

23) Farooq, M.S., Chaudhry, A.H., Shafiq, M. and Berhanu, G., 2011 Factors affecting students' quality of academic performance: a case of secondary school level. Journal of quality and technology management, 7(2), pp.1-14.

24) Fitsilis, P., Gerogiannis, V. and Anthopoulos, L., 2014. Ontologies for software project management: a review. Journal of Software Engineering and Applications, 7(13), p.1096.

25) Adams, J.D. and Jaffe, A.B., 1996. Bounding the effects of R\&D: an investigation using matched establishment-firm data(No. w5544). National bureau of economic research.

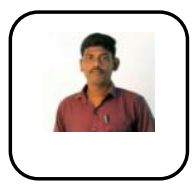

\section{AUTHORS PROFILE}

K. Thiyagarajan, Assistant Professor, Department of Science and Humanities, Bharath Institute of Higher Education and Research, Chennai, India.

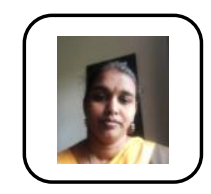

M. Shanmugapriya, Assistant Professor, Department of Science and Humanities, Bharath Institute of Higher Education and Research, Chennai, India.

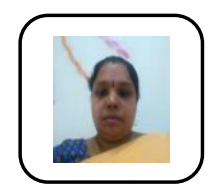

C. Archanapriya Assistant Professor, Department of Science and Humanities, Bharath Institute of Higher Education and Research, Chennai, India. 